University of Nebraska - Lincoln

DigitalCommons@University of Nebraska - Lincoln

Faculty Publications in Computer \& Electronics Electrical \& Computer Engineering, Department Engineering (to 2015)

2005

\title{
Technical Chair's Message
}

\author{
A. Beghdadi \\ Tadeusz Wysocki \\ University of Nebraska-Lincoln, wysocki@uow.edu.au
}

Follow this and additional works at: https://digitalcommons.unl.edu/computerelectronicfacpub

Part of the Computer Engineering Commons

Beghdadi, A. and Wysocki, Tadeusz, "Technical Chair's Message" (2005). Faculty Publications in Computer \& Electronics Engineering (to 2015). 24.

https://digitalcommons.unl.edu/computerelectronicfacpub/24

This Article is brought to you for free and open access by the Electrical \& Computer Engineering, Department of at DigitalCommons@University of Nebraska - Lincoln. It has been accepted for inclusion in Faculty Publications in Computer \& Electronics Engineering (to 2015) by an authorized administrator of DigitalCommons@University of Nebraska - Lincoln. 


\section{Technical Chair's Message}

We have organized an exciting technical program which includes tutorials, plenary sessions, and technical presentations. All technical submissions to the conference were based on full-length papers. Each paper has been assessed by at least two reviewers. This year marks the first time that a double-blind peer review process has been used in an ISSPA conference. Overall, the process was a great success with both authors and reviewers conforming to the double-blind review guidelines. We received 395 paper submissions, most of which were of very high quality. However, due to space limitations, only 228 articles were accepted for presentation at the conference. This gives an overall acceptance rate of $58 \%$ (or a $42 \%$ rejection rate), with an average score of accepted papers of $75 \%$. On behalf of the technical program committee, we would like to thank all authors for submitting their original work to the conference, technical program committee members for managing the reviews of the papers assigned to them, and all the reviewers for their hard work in assessing the papers.

The technical program consists of tutorials, three plenary sessions, twenty-five regular sessions and five special sessions on selected topics. For plenary sessions, Professor Ingemar J. Cox, from University College London, gives a presentation on digital signal processing and watermarking; Professor Braham Himed, from Air Force Research Laboratory, presents a signal processing-based approach to adaptivity on transmit; $\mathrm{Mr}$. Bimal Sareen, from AVAANA, discusses the technological challenges and opportunities in radio frequency identification (RFID). The regular sessions are divided into 13 oral sessions and 12 poster sessions. Please note that in accordance with ISSPA policy, the presentation mode is decided based on the number of accepted papers in a chosen topic and it does not reflect the quality of the papers. We are pleased to announce that the regular and special sessions report new and current developments in a wide range of topics, from radar and sonar processing, signal processing in communications, blind source separation to watermarking, speech processing, biomedical engineering, biometric signal processing and pattern classification.

Finally, we warmly invite you to the four days of stimulating scientific exchange and hope that the conference will be a successful event due to your participation.

A. Beghdadi and T. Wysocki

ISSPA 2005 Technical Co-Chairs 